6. Ulrich.-Klin. Monatsbl.f. Augenheilk., p. 242, 1882.

7. Hilgartner, H. L.-Amer. Jl. of Ophthal., Vol. XIV, pp. 886-7, 1931.

8. von Hölder. - Ref. Berlin.

9. Berlin.-Graefe-Saemisch, 1, Vol. VI, p. 604.

10. Würdemann, H. V.-See ref. No. 4 , p. 660.

11. Parsons, J. H.-Pathology of the Eye, Vol. IV, p. 1183.

12. Kiep, W. H.-Trans. Ophthal. Soc. U.K., Vol. XLVIII, p. 423.

13. Parsons, J. H.- See ref. No. 11, p. 1184.

14. Lang, W., and MacCallan, A. F.-Trans. Ophthal. Soc. U.K., Vol. XXII, p. 247, 1902.

15. Lang, W.-Ibid., Vol. XXI. p. 98

16. Lister, W., and Hine, M.-Ref. De Schweinitz, Diseases of the Eye, 10th edition, p. 568.

17. Würdemann, H. V.-See ref. No. 4, p. 732.

18. Marbaix.-Bull. Soc. belge d'ophtal., Vol LXIII, pp. 59-61, 1931.

20. Jackson, E.-Ophthal. Rec., August, 1904.

21. Colley, T.-Brit. Med. Jl., October 11, 1930.

22. De Wecker.-Maladies des Yeux, Vol. I, p. 803, 1862.

23. Juler, F.-Brit. Jl. of Ophthal., Vol. VIII. p. 466.

24. Marshall, J. C.-Brit. Med. Jl., p. 706, 1923.

25. Bride, T. M.-Trans. Ophthal. Soc. U.K., Vol. XI.V, p. 929, 1925.

26. Wissmann.-Zeitschr. f. Augenheilk., p. 187, 1919.

27. Dudinow, O. A.-Klin. Monatsbl. f. Augenheilk., pp. 373-380, 1932.

28. Shroff, C. N.-Brit. Jl. of Ophthal., Vol. XII, p. 94.

29. Sawhney, M. R.-Ibid., p. 115.

30. Kaul, S. N.-Ibid., p. 521 .

31. Geissler.-Ref. Würdemann, p. 712.

32. Causé.-Arch. Ophthal. Rec., May, 1900.

\title{
THE AFFINITY OF THE VITREOUS BODY TO DILUTE PLASMA GELS
}

BY

\author{
Sir Stewart Duke-Elder and E. B. Robertson \\ (FROM THE DEPARTMENT OF PHYSIOLOGY AND BIOCHEMISTRY, \\ UNIVERSITY COLLEGE, LONDON)
}

ONE would feel much happier about the whole question of the vitreous body if it were not so peculiar and different from everything else. In a monograph by one of us issued by this Journal (1930) a study of its physical and chemical properties was presented, wherein it was concluded that it was a gel made up upon the basis of specific protein constituents to which was physically absorbed quite an unusual quantity of watery solution (intraocular fluid). It was shown by ultra-microscopic observations that the gel "structure" consisted of minute colloid aggregations arranged in fibrillar form, and while it was pointed out that this resembled closely the appearance of soap gels, it showed little affinity with known organic structures. A further characteristic which seemed to place the vitreous gel in a class by itself was the extreme dilution of the gelable constituent ( 0.025 per cent.). It seemed of interest to determine if such properties were unique or 
if other organic material could be moulded into the same form. Observations were accordingly made on the behaviour of the gel which results from the dilution of blood plasma to such an extent that the concentrations of its protein constituents corresponded to that found in the vitreous body, and the surprising fact became evident that a gel was produced macroscopically identical with and indistinguishable from the vitreous.

Whole blood taken from a horse was transported to the laboratory in a cooled paraffin-coated jar to prevent coagulation, and was centrifuged in waxed tubes until a clear plasma resulted. This was diluted with normal saline in varying proportions and the resultant solutions allowed to coagulate at $30^{\circ} \mathrm{C}$. It was found that the diluted plasma would not coagulate unless inoculated with a few drops of uncentrifuged blood, or some of the serum expressed from a clot; thereafter, coagulation took place in one to three hours, the most dilute solutions being the last to clot.

The products obtained from the solutions whose concentrations ranged from 1 in 10 to 1 in 60 bore a striking resemblance to the vitreous body, especially that obtained from the solution of one volume of plasma in 50 volumes of normal saline. The concentration of fibrin in this gel is roughly the same as that of the residual protein in the vitreous body (viz., about 0.02 per cent.). The only material difference between the two systems was that the plasma gel was rather more rigid and friable than the vitreous body. Like the latter, the resultant gels were clear and almost colourless. When supported they were stable, but rapidly broke down under unbalanced mechanical stresses. Thustwo experiments described in the case of the vitreous body can be exactly reproduced with diluted plasma gel. When the gel was suspended from a clamp, a clear liquid immediately began to drip away from it, until finally only a fine thread of fibrin was left adhering to the clamp. Similarly, when a portion of the gel was left on a filter paper, a clear liquid passed through, while a thin skin of fibrin remained behind. Further, not only are the macroscopic appearances and the general physical characteristics extremely alike, but the ultra-microscopic appearances of the two were almost indistinguishable, both showing the same type of fibrillar basis, and the more precise physical properties such as the elasticity, are exactly parallel.

This close analogy is very striking and very interesting. It would seem possible, indeed, that the form of the vitreous body could be assumed by many organic systems. It is strange that the properties and behaviour of dilute plasma clots have not yet excited the notice or interest of physiologists, and it is probable that, were they to do so, considerable light would be thrown upon the reactions of the vitreous body. 